\title{
ARTICLE
}

\section{Binding motif of Ebselen in solution: Chalcogen and hydrogen bonds team up}

Received 00th January 20xx, Accepted 00th January 20xx DOI: $10.1039 / \times 0 \times x 00000 x$

\author{
Andrea Daolio, ${ }^{a}$ Patrick Scilabra, ${ }^{a}$ Maria Enrica Di Pietro, ${ }^{a}$ Chiara Resnati, ${ }^{b}$ Kari Rissanen, ${ }^{\mathrm{c}}$ and \\ Giuseppe Resnati*a
}

\begin{abstract}
Ebselen (2-phenyl-1,2-benzoselenazol-3(2H)one), a glutathione peroxidase mimic, is active against several RNA viruses, among others the retrovirus responsible for the COVID-19 pandemic. In this paper ${ }^{77} \mathrm{Se}$ and ${ }^{1} \mathrm{H}$ NMR studies of ebselen are reported and they identify the chalcogen bond $(\mathrm{ChB})$ and hydrogen bond $(\mathrm{HB})$ that are central in the landscape of interactions formed by the compound in solution. The selenium atom and the hydrogen atom at $\mathrm{C} 7 \mathrm{carbon}$ act as $\mathrm{ChB}$ and $\mathrm{HB}$ donors and the $\mathrm{O}$ and $\mathrm{N}$ atoms of neutral molecules function as acceptors. The ChB and the HB give rise to a bifurcated supramolecular synthon which fastens the interaction acceptor opposite to the N-Se covalent bond of the selenazole ring. It is known that the biologically important reaction of ebselen with cysteine thiol groups is favoured when selenium acts as chalcogen bond donor.
\end{abstract}

\section{Introduction}

Selenium has long been considered to be a toxic element, but in 1950's its reputation began to change dramatically as evidences emerged $^{1}$ that it is an essential trace element in many organisms, humans included. ${ }^{2}$ The initial source of selenium for natural organoselenium compounds are the selenate $\left(\mathrm{SeO}_{4}{ }^{2-}\right)$ and selenite $\left(\mathrm{SeO}_{3}{ }^{2-}\right)$ anions, two abundant forms of selenium in the soil. Plants reduce these anions to selenide ion that then affords selenocysteine (Sec) through a cascade of reactions. $\mathrm{Sec}$, the $21^{\text {st }}$ proteinogenic amino acid, ${ }^{3}$ is present in all three domains of life and is a major form of selenium in cells. In living organisms it is reversibly transformed into selenomethionine and Se-methylselenocysteine, two other naturally occurring amino acids. Another milestone in changing the hostile reputation of selenium was the discovery that glutathione peroxidase (GPx), a widespread enzyme that protects organisms from reactive oxygen species (ROS), is a selenoprotein that contains, at its active site, multiple Sec units that directly participate in ROS deactivation. ${ }^{4}$ Many other selenoproteins are now known, approximately 25 of them in humans ${ }^{5}$ of those thioredoxin reductases (TRxRs) and iodothyronine deiodinases (DIOs) are the most extensively studied. $^{6}$

\footnotetext{
Department of Chemistry, Materials, Chemical Engineering "Giulio Natta", Politecnico di Milano; via Mancinelli 7; I-20131 Milano; Italy.

${ }^{b}$. Recidency Program Clinical Pharmacology \& Toxicology, Università degli Stud della Campania "Luigi Vanvitelli"; Via Santa Maria Costantinopoli 16; I-80138 Napoli; Italy.

Department Chemistry; University of Jyväskylä; P.O Box 35; 40014, Jyväskylä; Finland.

d. + Electronic Supplementary Information (ESI) available: [nuclear magnetic resonance data, CSD and PDB databases surveys, fitting plots]. See DOI: 10.1039/x0xx00000x
}

Even after these milestones, various decades passed before selenium derivatives entered the toolbox of medicinal chemists. ${ }^{7}$ Two events that definitively manumitted selenium's bad reputation occurred in the 1980's when the antiviral activity of selenazofurin ${ }^{8}$ (2- $\beta$-D-ribofuranosyl-selenazole-4carboxamide, a selenium analogue of the broad spectrum antiviral drug ribavirin) was first reported and when ebselen ${ }^{9}$ (2-phenyl-1,2-benzoselenazol-3(2H)one) was described as a GPx-mimic. Currently Se is considered a particularly relevant element for the redox homeostasis in living organisms ${ }^{10}$ and researches targeting Se derivatives with GPx like activity are systematic. ${ }^{11}$ Ebselen has an extremely low cytotoxicity $\left(\mathrm{LD}_{50}\right.$ in rats $>4,600 \mathrm{mg} / \mathrm{kg}$, per os $)^{12}$ and its safety to humans has been thoroughly evaluated. ${ }^{13}$ It has been investigated as a possible treatment of reperfusion injury stroke, bipolar disorder, hearing loss and tinnitus. ${ }^{14}$ It shows anti-inflammatory, antiatherosclerotic, antibacterial, and cytoprotective properties and these activities have been all related to its GPx-mimic ability. $^{15}$

Ebselen is active against several RNA pathogens, among them hepatitis $\mathrm{C}$ virus (HCV) and human immunodeficiency viruses (HIV). The anti HIV activity ${ }^{16}$ of ebselen as well as its activity against other pathogens ${ }^{17}$ and its GPx-mimic action ${ }^{18}$ are all mediated by the formation of a covalent selenylsulfide ($\mathrm{Se}-\mathrm{S}-)$ linkage between the selenium of ebselen and the thiol group of a cysteine in the target protein (Table S.11). The analogous formation of a selenylsulfide linkage was proposed for the mechanism of action against $\mathrm{HCV}^{15 \mathrm{~b}}$ and has been documented for the activity against SARS-CoV-2, ${ }^{19}$ the retrovirus responsible for the COVID-19 pandemic. ${ }^{20}$ The -Se$\mathrm{S}-$ bond formation that produces the cysteine conjugates requires the cleavage of the selenazolone $\mathrm{Se}-\mathrm{N}$ bond. It has 
been proposed that this cleavage is crucial for the biological activity of ebselen and related compounds. ${ }^{10 a, 21}$

Noncovalent interactions are of pivotal importance in controlling molecular recognition phenomena and in determining the kinetic of reactions in chemical and biological systems. Calculation and solid state studies ${ }^{22}$ on ebselen showed that when selenium forms interactions with donors of electron density, viz. when forming chalcogen bonds $(\mathrm{ChBs}),{ }^{23}$ the $\mathrm{Se}-\mathrm{N}$ bond is lengthened and its cleavage is favoured. Importantly, ebselen analogues which form intramolecular ChBs are up to $10^{3}$ times more reactive in the -Se-S- bond formation than the parent compound ${ }^{10 \mathrm{c}}$ and arylselenium derivatives which form intramolecular $\mathrm{Se} \cdots \mathrm{O} / \mathrm{N} \mathrm{ChBs}$ are particularly effective GPx-mimics. ${ }^{25}$ In general, the formation/activation of selenosulfide bond mediate several important biological functions, viral entry into cells included. ${ }^{26}$

We reasoned that an assessment of the ability of ebselen to act as ChB donor in solution might afford indications on the interactions driving the binding of ebselen to biomolecular targets and might give useful information for tuning the rate of $\mathrm{Se}-\mathrm{N}$ bond activation and/or -Se-S- bond formation. In other words, new instruments are made available for the rational design of ebselen analogues with optimized affinity for the target active molecule, for instance $\mathrm{M}^{\text {pro }}$, a key SARS-CoV-2 enzyme which interacts with ebselen and mediates viral replication and transcription. ${ }^{19}$

Here we describe the results of ${ }^{1} \mathrm{H}$ and ${ }^{77} \mathrm{Se}$ NMR studies on ebselen solutions. It is shown that $\mathrm{ChB}$ and hydrogen bond (HB) cooperate in the binding phenomena involving ebselen. The Se atom and hydrogen atom at $\mathrm{C} 7$ carbon $(\mathrm{C} 7-\mathrm{H})$ act as $\mathrm{ChB}$ and $\mathrm{HB}$ donor sites and the $\mathrm{O}$ and $\mathrm{N}$ atoms of neutral molecules function as acceptors. The titration experiments using ${ }^{1} \mathrm{H}$ and ${ }^{77} \mathrm{Se}$ NMR prove that the formed $\mathrm{ChB}$ and $\mathrm{HB}$ give rise to a bifurcated supramolecular synthon (Scheme) which fastens the $\mathrm{ChB} / \mathrm{HB}$ bond acceptor opposite to the $\mathrm{N}-\mathrm{Se}$ covalent bond. ${ }^{22 b}$ The apparent association constants of some of the formed complexes are established. $\mathrm{ChB}$ has thus to be considered as one of the interactions which may contribute to the in vivo binding of ebselen to the target biomolecules where oxygen and nitrogen atoms are present. ${ }^{15 \mathrm{~b}}$

\section{Experimental Section}

\subsection{Materials and methods}

Ebselen, diphenyl diselenide, acetone- $\mathrm{d}_{6} \quad\left(\mathrm{DMK}-\mathrm{d}_{6}\right)$, dimethylsulfoxide- $\mathrm{d}_{6}$ (DMSO- $\left.\mathrm{d}_{6}\right)$, tetrahydrofurane- $\mathrm{d}_{8}$ (THF$\mathrm{d}_{8}$ ), hexamethylphosphoramide (HMPA) and other nondeuterated solvents were reagent grade compounds purchased from TCI and Sigma Aldrich and were used without further purification.

${ }^{1} \mathrm{H}$ and ${ }^{77} \mathrm{Se}$ NMR spectra were acquired on a Bruker Avance 300 at $7.05 \mathrm{~T}$ or a Bruker NEO 500 at $11.7 \mathrm{~T}$. The Larmor frequency for ${ }^{1} \mathrm{H}$ and ${ }^{77} \mathrm{Se}$ on those instruments were 300.13 and $57.22 \mathrm{MHz}$ or 500.13 and $95.37 \mathrm{MHz}$, respectively. The NEO instrument was equipped with a direct observe BBFO

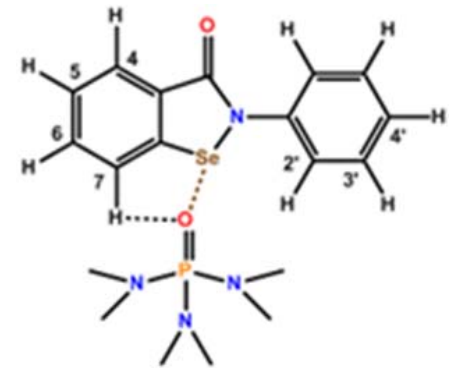

Scheme. Structural formula of ebselen/HMPA adduct with the numbering of carbon atoms. ChB (brown dotted line) and HB (black dotted line) cooperate in pinning the oxygen atom opposite to the Se-N bond.

iProbe with fully automatized tuning routine. The ${ }^{1} \mathrm{H}$ chemical shifts are reported in parts per million $(\delta)$ relative to tetramethylsilane (TMS). The ${ }^{77} \mathrm{Se}$ chemical shifts are reported in parts per million $(\delta)$ referenced to $0.25 \mathrm{M}$ diphenyl diselenide in DMSO- $\mathrm{d}_{6}$ at $448.00 \mathrm{ppm}$ as external standard contained in a coaxial capillary inserted in a $5 \mathrm{~mm}$ NMR tube. Selenous acid ( $1 \mathrm{M}$ solution in $\mathrm{D}_{2} \mathrm{O}$ ) was used for experimental setup and calibrations; the chemical shift of the Se resonance was set to $1300.1 \mathrm{ppm} .{ }^{27}$ All spectra were registered at $30.0{ }^{\circ} \mathrm{C}$.

\section{2. $\quad{ }^{77}$ Se spectra in different solvents}

Spectra of the Table were recorder by using $0.25 \mathrm{M}$ solutions of the ebselen or a saturated solution of the compound when its solubility in the used solvent was lower. Spectra were registered with a spectral width of $900 \mathrm{ppm}$, a recycling time of $5 \mathrm{~s}$, and enough scans to obtain a signal of both ebselen and diphenyl diselenide at a signal/noise ratio higher than 5 .

\subsection{Titration experiments}

Titrations were performed as follow: $50 \mathrm{mM}$ solutions of ebselen have been prepared using the three different deuterated solvents $\left(\right.$ DMK- $\mathrm{d}_{6}$, THF- $\mathrm{d}_{8}$, and DMSO- $\left.\mathrm{d}_{6}\right)$. Spectra were acquired with a spectral width of $500 \mathrm{ppm}$, a recycling time of $5 \mathrm{~s}$, and 128 scans. For each titration, solutions containing up to 15 equivalents of HMPA have been prepared using the $50 \mathrm{mM}$ ebselen solution for the HMPA dissolution. ${ }^{1} \mathrm{H}$ and ${ }^{77} \mathrm{Se}$ NMR spectra have been recorded of solutions containing different amounts of HMPA in order to obtain 12-13 points for the binding fit in DMK- $\mathrm{d}_{6}$ and $\mathrm{THF}-\mathrm{d}_{8}$. Less points were acquired for DMSO- $\mathrm{d}_{6}$ solutions. The Kc binding constants have been calculated by using the data fitting offered by online tools for supramolecular chemistry research and analysis with the option of 1:1 data fit for Host-Guest equilibria. ${ }^{28}$

\section{Results and discussion}

Electrophile-nucleophile interactions have been investigated in solution by using a variety of spectroscopic techniques and nuclear magnetic resonance (NMR) proved to be a particularly 
useful tool. ${ }^{29}$ For instance, interactions where the electrophile belongs to group 17 have been studied by using ${ }^{19} \mathrm{~F},{ }^{30} \mathrm{C},{ }^{13}$ and ${ }^{15} \mathrm{~N}^{32} \mathrm{NMR} ;{ }^{17} \mathrm{O},{ }^{33}{ }^{77} \mathrm{Se},{ }^{34}$ and ${ }^{125} \mathrm{Te}^{35}$ NMR were employed when the electrophile belongs to group 16 and ${ }^{13} \mathrm{C}^{36} \mathrm{NMR}$ to group 14.

\subsection{Analyses via ${ }^{77}$ Se NMR}

The natural abundance of ${ }^{77} \mathrm{Se}$ nucleus (7.6\%), its sensitivity (2.98 times that of $\left.{ }^{13} \mathrm{C}\right)$, and its spin $(\mathrm{I}=1 / 2)$ that enables for narrow resonance signals, make ${ }^{77} \mathrm{Se}$ a valuable candidate as an NMR reporter nucleus. ${ }^{37}$ Importantly, the ${ }^{77} \mathrm{Se}$ has a large chemical shift range $(\sim 3400 \mathrm{ppm})$ and is extremely sensitive to the chemical and electronic environment ${ }^{6,38}$ (e.g., the sensitivity of nucleus shielding to variations in electron distribution is several times greater than that of phosphorus) $)^{39}$ so that ${ }^{77} \mathrm{Se}$ is particularly suitable for studying aggregation phenomena. ${ }^{40}$

The ${ }^{77} \mathrm{Se}$ NMR spectra of ebselen in different solvents proved the ability of the compound to function as $\mathrm{ChB}$ donor towards different acceptor atoms. The use of the $\mathrm{ChB}$ acceptor as solvent was expected to maximize the possible $\mathrm{ChB}$ formation by that acceptor. Indeed, the observed ${ }^{77} \mathrm{Se}$ chemical shifts span over fifty ppm range (Table) on solvent change. Oxygen and nitrogen atoms belonging to a variety of functionalities work as effective $\mathrm{ChB}$ acceptor sites. The heteroatoms can be $\mathrm{sp}, \mathrm{sp}^{2}$, or $\mathrm{sp}^{3}$ hybridized and some of employed solvents were chosen as containing functionalities that mimic electron donor moieties commonly present in biological systems (e.g., DMF and DMA were used as mimics of the carbonyl units of peptides and HMPA as mimic of the $\mathrm{P}=\mathrm{O}$ unit of phosphorylated compounds).

While observed ${ }^{77} \mathrm{Se}$ chemical shifts changes represent the combined result of all interactions between ebselen and the solvent, it seems plausible that the single most important contribution to the $\Delta(\delta \mathrm{Se})$ comes from the $\mathrm{Se} \cdots$ solvent $\mathrm{ChB}$ formation. This hypothesis is supported by the solubility profile of the compound. Ebselen solubility is very low in noncoordinating aprotic hydrocarbon solvents (e.g., $n$-hexane, $n$ pentane) but becomes intermediate in solvents containing $\mathrm{N}$ and $\mathrm{O}$ atoms, suggesting that ebselen dissolution is driven by the formation of $\mathrm{Se} \cdots \mathrm{N} / \mathrm{O} \mathrm{ChBs}$ which override the $\mathrm{Se} \cdots \mathrm{O} \mathrm{ChBs}$ observed in the crystal structure of the pure ebselen. ${ }^{22 b}$ Moreover, the solvent induced $\Delta(\delta \mathrm{Se})$ values shown by ebselen are much larger than those shown by other selenium functional groups, e.g., the selenium chemical shift of ebselen,

Table. ${ }^{77}$ Se chemical shifts $(\delta, \mathrm{ppm})$ of ebselen in different solvents. ${ }^{\ddagger}$

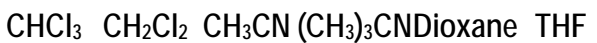

Ebselen $\quad 960.95 \quad 957.57948 .41935 .92 \quad 945.90936 .50$

DMK DMFa DMA DMSO PyridineHMPA

$\begin{array}{lllllll}\text { Ebselen } & 941.41 & 929.55 & 925.38 & 914.17 & 912.11 & 905.67\end{array}$

${ }^{\mathrm{a}} \mathrm{DMF}=$ dimethylformamide. ${ }^{\mathrm{b}} \mathrm{DMA}=$ dimethylacetamide. diphenyldiselenide (Table S.1), or a selenocarbonyl derivative ${ }^{41}$ in solution of THF, an intermediate strength $\mathrm{ChB}$ acceptor, is 24, 7, and $1 \mathrm{ppm}$ upfield with respect to corresponding solutions in chloroform (a poorly coordinating solvent which was assumed as reference solvent). This proves that the tendency of ebselen to act as $\mathrm{ChB}$ donor in solution is remarkable and that the interaction may play a major role in the binding pattern of the compound.

Analyses of the Cambridge Structural Database (CSD) show that $\mathrm{ChB}$ systematically controls or affects the crystal packing of ebselen and its derivatives, this being a further indication that the compound may act as a robust $\mathrm{ChB}$ donor in solution. The by-far shortest contact in crystalline ebselen is the intermolecular $\mathrm{Se} \cdots \mathrm{O} \mathrm{ChB},{ }^{22 \mathrm{~b}}$ the corresponding normalized contact $^{\S}(\mathrm{Nc})$ being 0.74 . Molecules are so tightly packed in the crystal that its density is $1.647 \mathrm{~g} / \mathrm{cm}^{3}$ (at room temperature). The $\mathrm{Nc}$ value for the intermolecular $\mathrm{Se} \cdots \mathrm{N} \mathrm{ChB}$ in the ebselen/4-dimethylaminopyridine cocrystal is as small as 0.69 . $^{22 \mathrm{a}}$ A CSD survey reveals that 29 structures contain the 2phenyl-1,2-benzoselenazol-3(2H)one moiety and 23 of them ( $79 \%$ ) show the presence of a $\mathrm{Se} \cdots \mathrm{O} / \mathrm{N} \mathrm{ChB}^{\dagger}$ (Table S.8). $\mathrm{CSD}$ analyses indicates also that in ebselen the electron withdrawing ability of the $-\mathrm{NC}(=\mathrm{O})$ residue bound to selenium plays a major role in determining the strong $\mathrm{ChB}$ donor ability of the compound. In fact, when weaker electron withdrawing residues are covalently bonded to the selenium atom, the occurrence of $\mathrm{Se} \cdots \mathrm{O} / \mathrm{N}$ ChBs decreases dramatically, e.g., it is $14 \%$ in compounds containing the $\mathrm{C}-\mathrm{Se}-\mathrm{C}$ moiety (Table S.9). $\mathrm{X}$-ray crystallography charge density studies and atom-inmolecules theoretical analysis further prove that $\mathrm{Se}$ atom in ebselen can functions as a particularly good $\mathrm{ChB}$ donor. ${ }^{22 \mathrm{~b}}$

Consistent with the similar nature of the $\mathrm{ChB}$ and the halogen bond $(\mathrm{HaB}){ }^{23 \mathrm{~b}}$ close analogies exist between the solvent induced chemical shift changes of ${ }^{77} \mathrm{Se}$ signal in ebselen and the solvent induced changes of ${ }^{19} \mathrm{~F}$ signal in iodoperfluorocarbons. ${ }^{30}$ For both $\mathrm{ChB}$ and $\mathrm{HaB}$, the electron donor site can be a lone pair on an $\mathrm{sp}^{3}, \mathrm{sp}^{2}$, or $\mathrm{sp}$ atom. The greater is the ability of the solvent to donate electron density to the electrophilic selenium or halogen atom, the larger are the observed upfield changes of chemical shift. For instance, the ${ }^{77} \mathrm{Se}$ signal of ebselen and the ${ }^{19} \mathrm{~F}$ signals of $-\mathrm{CF}_{2} \mathrm{I}$ groups (e.g., in $\mathrm{ICF}_{2} \mathrm{CF}_{2} \mathrm{I}$ ) occur at higher fields in pyridine and DMSO than in acetonitrile and THF. The greater donation of electron density by the two former solvents to the $\mathrm{ChB}$ and $\mathrm{HaB}$ donor aroms causes increased electron density and stronger shielding effect at selenium and fluorine and corresponding NMR signals are at higher fields. ${ }^{77} \mathrm{Se}$ signal of ebselen and ${ }^{19} \mathrm{~F}$ signal of $\mathrm{CF}_{2} \mathrm{I}$ groups are at higher fields when the solvent is DMSO than when is acetone, suggesting that in both $\mathrm{ChB}$ and $\mathrm{HaB}$ the donation of electron density by a given atom increases with its negative charge.

These results indicate that it is possible to evaluate the intramolecular $\mathrm{ChB}$ formation between ebselen and a neutral $\mathrm{ChB}$ acceptor in solution by ${ }^{77} \mathrm{Se}$ NMR. The most upfield shifted ${ }^{77}$ Se signal for ebselen was obtained when HMPA was 
used as the solvent. The formation of ebselen/HMPA complex was monitored through ${ }^{77} \mathrm{Se}$ and ${ }^{1} \mathrm{H}$ NMR titrations of solutions where the solvents were $\mathrm{ChB}$ acceptors weaker than HMPA.

The ${ }^{77} \mathrm{Se}$ NMR spectra of ebselen in acetone- $\mathrm{d}_{6}$ and in the presence of trace amounts of HMPA (e.g., $<0.05$ eq.) can hardly be distinguished from solutions in pure acetone. ${ }^{77} \mathrm{Se}$ signals progressively move upfield on addition of incremental amounts of HMPA (Fig. 1, Table S.2). A single peak was observed in all spectra, no signal splitting was noticed independent of the ebselen:HMPA ratio, showing that formation of ebselen/HMPA complexes is rapid at room temperature on NMR time scale. The increased shielding of selenium in the presence of incremental amounts of HMPA indicates that the $\mathrm{ChB}$ driven formation of an ebselen/HMPA complex is due to the fact that the more negative oxygen of HMPA functions as the ChB acceptor with preference over the less negative oxygen of acetone. By fitting the observed upfield shifts (1:1 pairing of ebselen and HMPA), an association constant Kc of $4.63 \mathrm{M}^{-1}$ was calculated (Fig. 2).

A similar behaviour was observed when $\mathrm{THF}-\mathrm{d}_{8}$ was used as solvent. Also with this solvent, no signal splitting or broadening has been ever observed and, at the same ebselen:HMPA ratios, upfield shifts were slightly larger than in acetone (Fig. S.1, Table S.3). The apparent association constant of the ebselen/HMPA complex in tetrahydrofurane is $8.43 \mathrm{M}^{-1}$, marginally greater than in acetone. Upfield shifts of ${ }^{77} \mathrm{Se}$ signal were observed also when incremental amounts of HMPA were added to solutions of the ebselen in dimethylsulfoxide- $\mathrm{d}_{6}$, but they were very minor even at highest HMPA:ebselen ratios (Table S.4, Fig. S.2) and a reliable association constant of the ebselen/HMPA complex could not be calculated in this solvent.

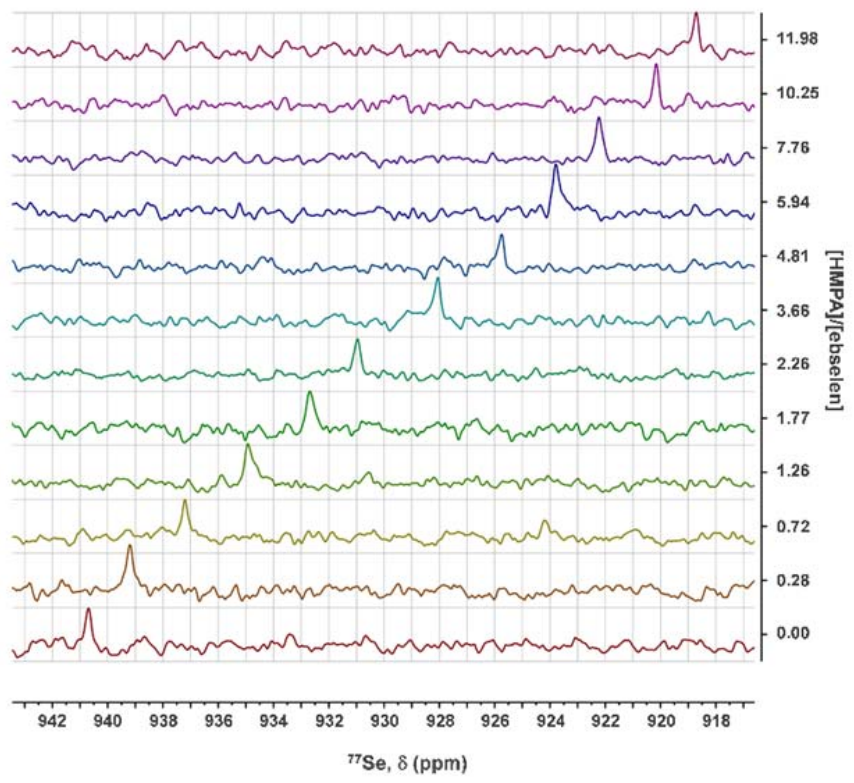

Fig. $1{ }^{77}$ Se NMR spectra of ebselen solutions in acetone- $d_{6}$ on increasing $[\mathrm{HMPA}] /[$ ebselen] ratio (ordinate on the right).

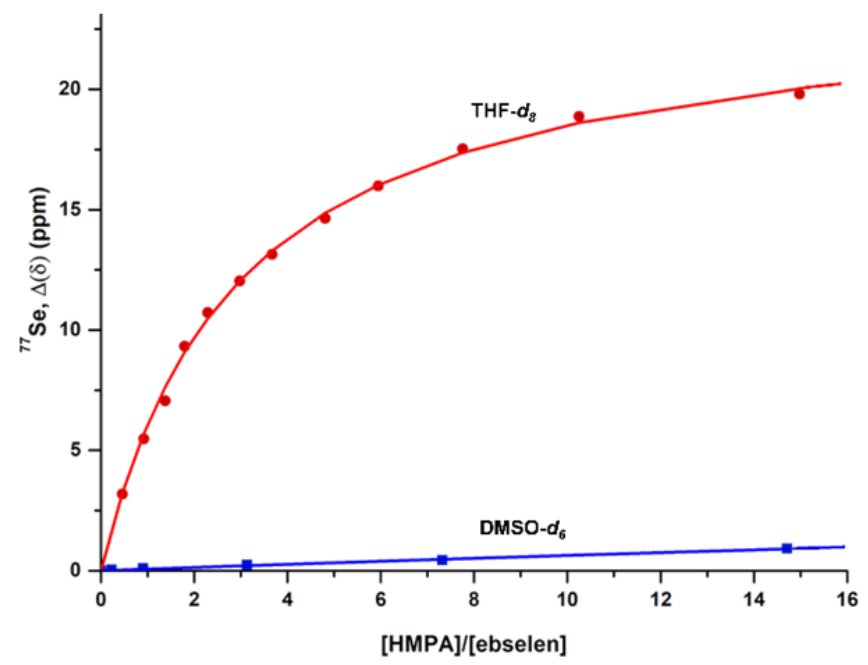

Fig. 2 Plotted $\Delta \delta$ of ${ }^{77}$ Se of ebselen in DMK- $\mathrm{d}_{6}$ and DMSO- $\mathrm{d}_{6}$ on addition of incremental amounts of HMPA $\left(\Delta \delta=\delta_{0}-\delta_{i}\right.$, where $\delta_{0}$ and $\delta_{i}$ are the chemical shifts of a solution of pure ebselen and of a solution containing the $i$-th aliquot of HMPA).

DMSO, a stronger ChB acceptor than DMK and THF (Table), competes with HMPA in serving as acceptor more effectively than the two other solvents.

\subsection{Analyses via ${ }^{1} \mathrm{H}$ NMR}

${ }^{1} \mathrm{H}$ NMR spectra of the same solutions studied via ${ }^{77} \mathrm{Se}$ NMR revealed that an $\mathrm{HB}$, involving $\mathrm{C} 7-\mathrm{H}$ as donor site, contributes to the complex formation. This adds structural information on the ebselen/HMPA complex formed in solution. All ebselen protons show chemical shift changes on HMPA addition; they all are quite small (Tables S.5-7), but those of C7-H. On incremental addition of HMPA this proton moves downfield while all other protons, but $\mathrm{C} 2{ }^{\prime}-\mathrm{H}$, are moved upfield. This behaviour is shown in both acetone (Figs. 3 and 4) and THF and DMSO (Figs. S.3 and S.4) suggesting that, in the three solvents, an $\mathrm{HB}$ is formed between $\mathrm{C} 7-\mathrm{H}$ and HMPA oxygen. The $\mathrm{N}-\mathrm{Se} \cdots \mathrm{O} \mathrm{ChB}$ and the $\mathrm{C} 7-\mathrm{H} \cdots \mathrm{O} \mathrm{HB}$ mutually favour their formation and cooperate in pinning the HMPA oxygen opposite to the $\mathrm{N}-\mathrm{Se}$ covalent bond, where calculations show there is the most positive $\sigma$-hole at selenium. ${ }^{22 b}$

Changes of C7-H chemical shift are similar when DMK and THF are used as solvents and they are much greater than when DMSO is used. Parallel to what suggested by ${ }^{77} \mathrm{Se}$ NMR analyses, this indicates that DMSO competes with HMPA, in serving as HB acceptor, more successfully than DMK and THF. The Kc value for the ebselen/HMPA adduct, calculated by fitting $\mathrm{C} 7-\mathrm{H}$ chemical shift changes for a 1:1 complex, are 5.79 $\mathrm{M}^{-1}$ in DMK- $\mathrm{d}_{6}$ solution and $9.79 \mathrm{M}^{-1}$ in THF- $\mathrm{d}_{8}$ solution. When DMSO was used as the solvent, a reliable calculation of $\mathrm{Kc}$ was prevented by the too small changes of $\mathrm{C} 7-\mathrm{H}$ chemical shifts observed on HMPA addition. Titrations via ${ }^{1} \mathrm{H}$ and ${ }^{77} \mathrm{Se}$ NMR measurements give consistent relative tendencies for the 

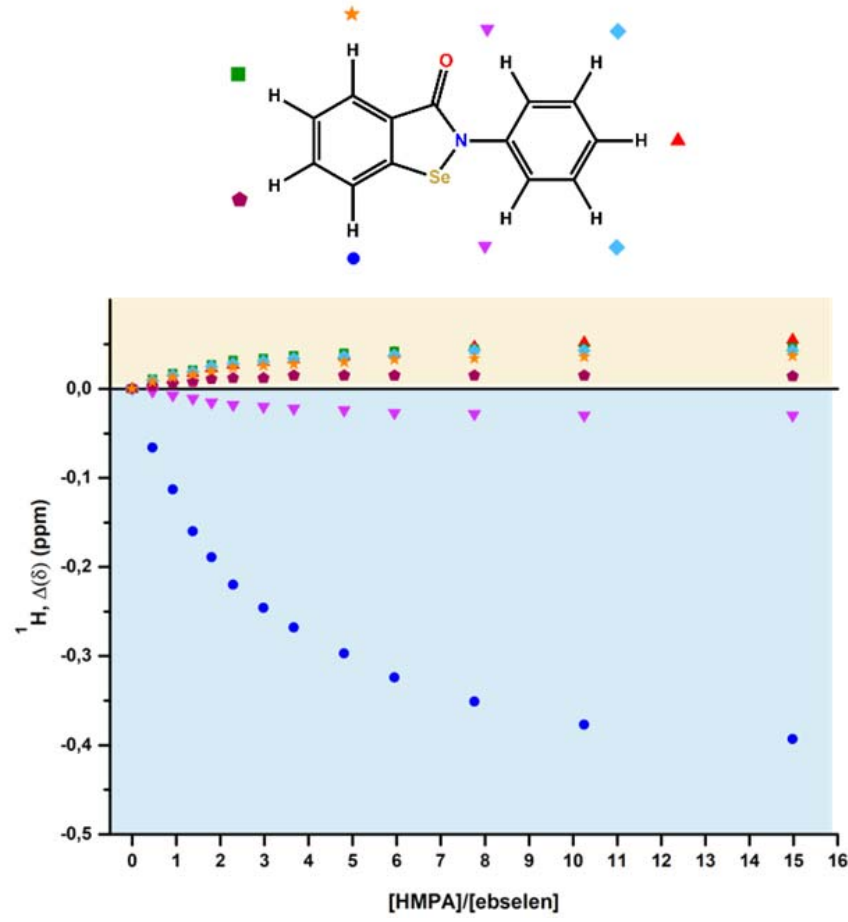

Fig. 3 Plotted $\Delta \delta$ of proton signals of ebselen in $D M K-d_{6}$ in the presence of incremental amounts of HMPA.

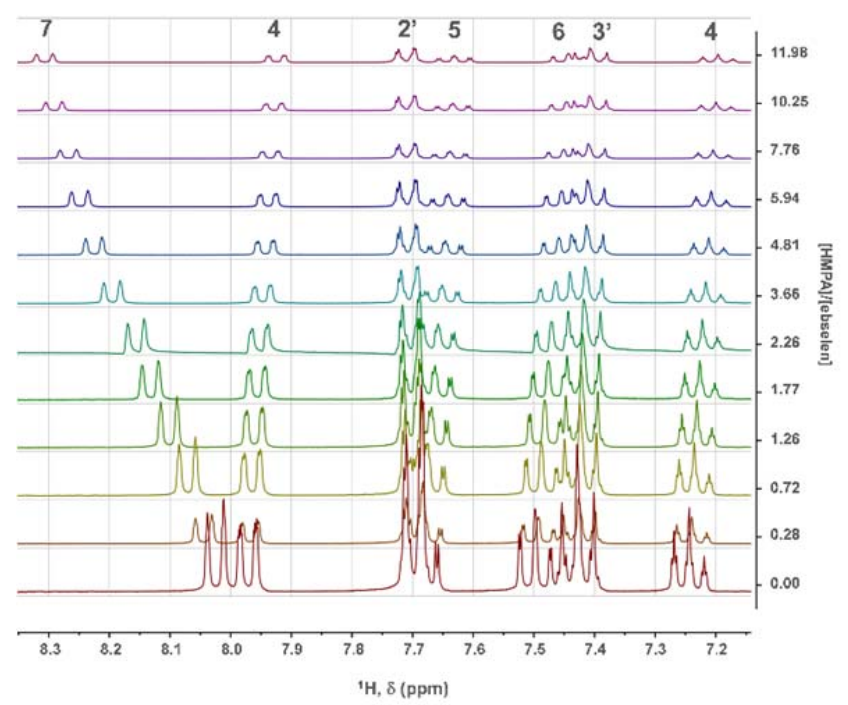

Fig. $4{ }^{1} \mathrm{H}$ NMR spectra of ebselen solutions in DMK- $\mathrm{d}_{6}$ on increasing [HMPA]/[ebselen] ratio (ordinate on the right). Numbers at the top gives peaks assignment according to the atoms numbering in the Scheme.

complex formation which varies in the order THF $\geq$ DMK $>>$ DMSO. Kc values established via ${ }^{1} \mathrm{H}$ NMR are slightly greater than those established via ${ }^{77} \mathrm{Se}$ NMR in both DMK and THF. This might suggest that the existence in solution of the ebselen/HMPA complex is associated with the presence of the bifurcated $\mathrm{C} 7-\mathrm{H} \cdots \mathrm{O} \cdots \mathrm{Se}-\mathrm{N}$ supramolecular synthon and, to a lesser extent, of the monofurcated $\mathrm{C} 7-\mathrm{H} \cdots \mathrm{O}$ synthon. These two synthons cause different changes of Se and $\mathrm{H}$ chemical shifts of ebselen and the observed $\Delta(\delta \mathrm{Se})$ and $\Delta(\delta \mathrm{H})$ values are the combined result of these different contributions. A CSD analysis confirms that the bifurcated supramolecular synthon is the favoured pattern in the interaction landscape of ebselen in the solid. ${ }^{44}$ The presence of the monofurcated $\mathrm{C} 7-\mathrm{H} \cdots \mathrm{O}$ synthon in solution might be enabled by the dynamic character of association processes in the liquid.

\section{Conclusions}

In summary, ebselen is a compound which displayed a quite promising pharmacological profile. In particular, it showed, out of $\sim 10000$ known pharmacologically active compounds, the strongest inhibition of $\mathrm{M}^{\text {pro }}$, a key enzyme which mediates replication of SARS-CoV-2 virus. ${ }^{19}{ }^{77} \mathrm{Se}$ and ${ }^{1} \mathrm{H}$ NMR studies reported in this paper prove that ebselen forms $\mathrm{ChB}$ and $\mathrm{HB}$ in solution with $\mathrm{O}$ and $\mathrm{N}$ atoms. The main binding mode in various solvents is a bifurcated supramolecular synthon where the $\mathrm{ChB}$ and $\mathrm{HB}$ cooperate in fastening the lone-pair donor atom on the elongation of the $\mathrm{N}-\mathrm{Se}$ covalent bond. $\mathrm{ChB}$ has thus to be considered as one of the interactions which may mediate the binding of ebselen to biomolecular targets where oxygen and nitrogen atoms are typically present. The interaction may also help in designing ebselen analogues with optimized pharmacological activity. This specific ability complements the numerous, important, and general roles that $\mathrm{ChB}$ has in several fields, ${ }^{45}$ e.g. medicinal chemistry, ${ }^{46}$ catalyses,${ }^{47}$ and anion binding and trasport. ${ }^{48}$ Finally, ${ }^{77} \mathrm{Se}$ NMR is shown to be a powerful tool for studying association equilibria in solution, specifically for improving the current knowledge of $\mathrm{ChB}$ also in the presence of cooperating/competing interactions.

\section{Conflicts of interest}

There are no conflicts to declare.

\section{Acknowledgements}

G.R. gratefully acknowledge financial support from Fondazione Cariplo (Project no. RFJ4RIST01).

\section{Notes and references}

$\mp{ }^{77}$ Se NMR spectra of ebselen solutions in simple amines (e.g., $\mathrm{Et}_{3} \mathrm{~N}$ and $n-\mathrm{Bu}_{3} \mathrm{~N}$ ) could not be obtained as a reaction occurred after dissolution.

$\S$ The "normalized contact" Nc for an interaction between atoms $i$ and $j$ is the ratio $D i j /(r v d W, i+r v d W, j)$ where $D i j$ is the experimental distance separating atoms $i$ and $j$ and $r v d W, i$ and rvdW, $j$ are the van der Waals radii ${ }^{42}$ of atoms $i$ and $j$. If the electron donor $\mathrm{j}$ is an anionic atom, $\mathrm{rvdW}, \mathrm{j}$ is substituted by the Pauling ionic radius ${ }^{43}$ of the anion atom $j$. Nc is a useful indicator, allowing for a more rigorous comparison of 
separations between different interacting atoms than absolute values of interaction lengths.

+ It was assumed that a ChB is present in the crystal when the interatomic Se $\cdots \mathrm{O} / \mathrm{N}$ distance is below sum of van der Waals radii $^{42}$ and the $\mathrm{N}-\mathrm{Se} \cdots \mathrm{O} / \mathrm{N}$ and $\mathrm{C}-\mathrm{Se} \cdots \mathrm{O} / \mathrm{N}$ angles span the range $155-180^{\circ}$.

1 K. Schwarz and C. M. J. Foltz, J. Am. Chem. Soc., 1957, 79, 3292-3203.

2 E. J. Lenardão, C. Santi and L. Sancineto, New Frontiers in Organoselenium Compounds, Springer International Publishing, 6330 Cham, Switzerland, 2018.

3 V. M. Labunskyy, D. L. Hatfield and V. N. Gladyshev, Physiol. Rev., 2014, 94, 739-777.

4 J. T. Rotruck, A. L. Pope, H. E. Ganther, A. B. Swanson, D. G. Hafeman and W. G. Hoekstra, Science, 1973, 179, 588-590; R. Prabhakar, T. Vreven, K. Morokuma, D. G. Musaev, Biochemistry, 2005, 44, 11864-11871.

5 G. V. Kryukov, S. Castellano, S. V. Novoselov, A. V. Lobanov, O. Zehtab, R. Guigó and V. N. Gladyshev, Science, 2003, 300, 1439-1443.

6 J. C. Avery and P. R. Hoffmann, Nutrients, 2018, 10, 1203; H. Sies and L. Packer, Methods in Enzymology, Protein Sensors and Reactive Oxygen Species - Part A: Selenoproteins and Thioredoxin, Academic Press, San Diego, CA, USA, 2002, vol. 347, 3-511.

7 V. Kumar Jain and K. I. Priyadarsini, Organoselenium Compounds in Biology and Medicine. Synthesis, Biological and Therapeutic Treatments, RSC, London (UK), 2018; M. Ninomiyaa, D. R. Garudb and M. Koketsua, Coord. Chem. Rev., 2011, 255, 2968-2990.

8 J. J. Kirsi, J. A. North, P. A. McKernan, B. K. Murray, P. G. Canonico, J. W. Huggins, P. C. Srivastava and R. K. Robins, Antimicrob. Agents Chemother., 1983, 24, 353-361; J. D. Morrey, D. F. Smee, R. W. Sidwell and C. Tseng, Antivir. Res. 2002, 55, 107-116.

9 A. Müller, E. Cadenas, P. Graf and H. Sies, Biochem. Pharmacol., 1984, 33, 3235-3239.

10 (a) K. P. Bhabak and G. Mugesh, Chem. Eur. J., 2007, 13, 4594-4601; (b) S. S. Zade, H. B. Singh and R. J. Butcher Angew, Chem. Int. Ed., 2004, 43, 4513-4515; (c) S. J. Balkrishna, S. Kumar, G. K. Azad, B.S. Bhakuni, P. Panini, N Ahalawat, R. S. Tomar, M. R. Detty and S. Kumar, Org. Biomol. Chem., 2014, 12, 1215-1219.

11 S. Kumar, J. Yan, J. F. Poon, V. P. Singh, X. Lu, M. K. Ott, L. Engman and S. Kumar, Angew. Chem. Int. Ed., 2016, 55 3729-3733; Z. Luo, J. Sheng, Y Sun, C. Lu, J. Yan, A. Liu, H. Luo, L. Huang and X. Li, J. Med. Chem., 2013, 56, 9089-9099.

12 J. W. Renson, M. Etschenberg and J. Winkelmann, Patent US4352799A 1982.

13 J. Kil, E. Lobarinas, C. Spankovich, S. K. Griffiths, P. J. Antonelli, E. D. Lynch and C. G. Le Prell, Lancet, 2017, 390, 969-979; E. Lynch and J. Kil, Semin. Hear., 2009, 30, 47-55; C. Masaki, A. L. Sharpley, C. M Cooper, B. R. Godlewska, N. Singh, S. R. Vasudevan, C. J. Harmer, G. C. Churchill, T. Sharp, R. D. Rogers and P. J. Cowen, Psychopharmacology (Berl), 2016, 233, 2655-2661.

14 G. K. Azad and R. S. Tomar, Mol. Biol. Rep., 2014, 41, 48654879.

15 (a) N. Singh, A. C. Halliday, J. M. Thomas, O. V. Kuznetsova, R. Baldwin, E. C. Y. Woon, P.K. Aley, I. Antoniadou, T. Sharp, S. R. Vasudevan and G. C Churchill, Nature Comm., 2013, 4 1332; (b) S. Mukherjee, W. S. Weiner, C. E. Schroeder, D. S. Simpson, A. M. Hanson, N. L. Sweeney, R. K. Marvin, J. Ndjomou R. Kolli, D. Isailovic, F. J. Schoenen and D. N. Frick, ACS Chem. Biol., 2014, 9, 2393-2403.

16 S. Thenin-Houssier, I. Mitchelle, S. de Vera, L. Pedro-Rosa, A. Brady, A. Richard, B. Konnick, S. Opp, C. Buffone, J.
Fuhrmann, S. Kota, B. Billack, M. Pietka-Ottlik, T. Tellinghuisen, H. Choe, T. Spicer, L. Scampavia, F. DiazGriffero, D. J. Kojetin and S. T. Valentea, Antimicrob. Agents Chemother., 2016, 60, 2195-2208.

17 M. de Munnik, C. T. Lohans, P. A. Lang, G. W. Langley, T. R. Malla, A. Tumber, C. J. Schofield and J. Brem, Chem. Commun., 2019, 55, 10214-10217. (b) L. Favrot, D. H. Lajiness and D. R. Ronning, J. Biol. Chem., 2014, 289, 2503125040; H. M. Berman, J. Westbrook, Z. Feng, G. Gilliland, T. N. Bhat, H. Weissig, I. N. Shindyalov, P. E. Bourne, Nucleic Acids Research, 2000, 28, 235-242.

18 T. Sakurai, M. Kanayama, T. Shibata, K. Itoh, A. Kobayashi, M. Yamamoto and K. Uchida, Chem. Res. Toxicol., 2006, 19, 1196-1204.

19 Jin, X. Du, Y. Xu, Y. Deng, M. Liu, Y. Zhao, B. Zhang, X. Li, L. Zhang, C. Peng, Y. Duan, J. Yu, L. Wang, K. Yang, F. Liu, R. Jiang, X. Yang, T. You, X. Liu, X. Yang, F. Bai, H. Liu, X. Liu, L. W. Guddat, W. Xu, G. Xiao, C. Qin, Z. Shi, H. Jiang, Z. Rao and H. Yang, Nature, 2020, 582, 289-293.

20 N. Zhu, D. Zhang, W. Wang, X. Li, B. Yang, J. Song, X. Zhao, B. Huang, W. Shi, R. Lu, P. Niu, F. Zhan, X. Ma, D. Wang, W. Xu, G. Wu, G. F. Gao and W. Tan, N. Engl. J. Med., 2020, 382, 727-733; F. Wu, S. Zhao, B. Yu, Y.-M. Chen, W. Wang, Z.-G. Song, Y. Hu, Z.-W. Tao, J.-H. Tian, Y.-Y. Pei, M.-L. Yuan, Y.-L. Zhang, F.-H. Dai, Y. Liu, Q.-M. Wang, J.-J. Zheng, L. Xu, E. C. Holmes and Y.-Z. Zhang, Nature, 2020, 579, 265-269.

21 T. Schewe, Gen. Pharmacol. 1995, 26, 1153-1169.

22 (a) T. Fellowes and J. M. White, CrystEngComm, 2019, 19, 1539-1542; (b) S. P. Thomas, K. Satheeshkumar, G. Mugesh and T. N. Guru Row, Chem. Eur. J., 2015, 21, 6793-6800; (c) L. Dupont, O. Dideberg and P. Jacquemin, Acta Crystallogr., Cryst. Struct. Commun. 1990, C46, 484-486.

23 (a) C. B. Aakeroy, D. L. Bryce, G. R. Desiraju, A. Frontera, A. C. Legon, F. Nicotra, K. Rissanen, S. Scheiner, G. Terraneo, P. Metrangolo and G. Resnati, Pure Appl. Chem., 2019, 91, 1889-1892; (b) P. Scilabra, G. Terraneo, G. Resnati, Acc. Chem. Res., 2019, 52, 1313-1324.

24 S. J. Balkrishna, S. Kumar, G. K. Azad, B.S. Bhakuni, P. Panini, N. Ahalawat, R. S. Tomar, M. R. Detty and S. Kumar, Org. Biomol. Chem., 2014, 12, 1215-1219.

25 S. Shimodaira, Y. Asano, K. Arai and M. Iwaoka, Biochemistry, 2017, 56, 5644-5653; D. Bhowmick, S. Srivastava, P. D. Silva and G. Mugesh, Angew. Chem. Int. Ed., 2015, 54, 8449-8453; B. K. Sarma and G. Mugesh, J. Am. Chem. Soc., 2005, 127, 11477-11485; V. P. Singh, H. B. Singh and R. J. Butcher, Eur. J. Org. Chem. 2011, 5485-5497; H. Komatsu, M. Iwaoka and S. Tomoda, Chem. Commun. 1999, 205-206.

26 (a) Y. Cheng, A.-T. Pham, T. Kato, B. Lim, D. Moreau, J. LópezAndarias, L. Zong, N. Sakai and S. Matile, ChemRxiv. Preprint 2020, doi: 10.26434/chemrxiv.12906533.v1; (b) N. Chuard, A. I. Poblador-Bahamonde, L.. Zong, E. Bartolami, J. Hildebrandt, W. Weigand, N. Sakaia and S. Matile, Chem. Sci. 2018, 9, 1860-1866; (c) C. Chandra Tjin, K. D. Otley, T. D. Baguley, P. Kurup, J.Xu, A. C. Nairn, P. J. Lombroso and J. A. Ellman, ACS Cent. Sci. 2017, 3, 1322-1328.

27 J. Milne, Magn. Reson. Chem., 1993, 31, 652-655.

28 http://app.supramolecular.org/bindfit/

29 B. Watson, O. Grounds, W. Borley and S. V. Rosokha, Phys. Chem. Chem. Phys., 2018, 20, 21999-22007; S. K. Nayak, G. Terraneo, Q. Piacevoli, F. Bertolotti, P. Scilabra, J. T. Brown, S. V. Rosokha and G. Resnati, Angew. Chem. Int. Ed., 2019, 131, 12586-12589. G. Resnati, E. Boldyreva, P. Bombicz and M. Kawano, IUCrJ, 2015, 2, 675-690.

30 P. Metrangolo, W. Panzeri, F. Recupero and G. Resnati, J. Fluorine Chem., 2002, 114, 27-33.

31 M. Baldrighi, G. Cavallo, M. R. Chierotti, R. Gobetto, P. Metrangolo, T. Pilati, G. Resnati and G. Terraneo, Mol. Pharmaceutics, 2013, 10, 1760-1772. 
32 T. Messina, P. Metrangolo, W. Panzeri, E. Ragg and G. Resnati, Tetrahedron Lett., 1998, 39, 9069-9072.

33 M. Iwaoka, H. Komatsu, T. Katsuda and S. Tomoda, J. Am. Chem. Soc., 2004, 126, 5309-5317; H. Komatsu, M. Iwaoka and S. Tomoda, Chem. Commun., 1999, 205-206.

34 V. Kumar, C. Leroy and D. L. Bryce, CrystEngComm, 2018, 20 6406-6411; G. Mugesh, A. Panda, H. B. Singh and R. J. Butcher, Chem. Eur. J., 1999, 5, 1411-1421; M. Iwaoka and S. Tomoda, J. Am. Chem. Soc., 1996, 118, 8077-8084.

35 C. Ho, P. Szydlowski, J. Sinclair, P. J. W. Elder, J. Kübel, C. Gendy, L. M. Lee, H. Jenkins, J. F. Britten, D. R. Morim and I. Vargas-Baca, Nature Comm., 2016, 7, 11299.

36 S. A. Southern and D. L. Bryce, J. Phys. Chem. A, 2015, 119, 11891-11899.

37 L. A. Silks, R. B. Dunlap and J. D. Odom, J. Am. Chem. Soc., 1990, 112, 4979-4982.

38 L. A. Silks, J. Peng, J. D. Odom and R. B. Dunlap, J. Org. Chem., $1991,56,6733-6736$.

39 J. Oppenheimer and L. A. Silks III, J. Labelled Comp. Radiopharm., 1996, 38, 281-284.

40 J. Y. C. Lim, J. Y. Liew and P. D. Beer, Chem. Eur. J. 2018, 24, 14560-14566.

41 J. Peng, M. E. Barr, D. A. Ashbum, L. Lebioda, A. R. Garber, R. A. Martinez, J. D. Odom, R. B. Dunlap and L. A. Silks III, J. Org. Chem., 1995, 60, 5540-5549.

42 A. Bondi, J. Phys. Chem., 1964, 68, 441-451; M. Mantina, A. C. Chamberlin, R. Valero, C. J. Cramer and D. G. Truhlar, J. Phys. Chem. A., 2009, 113, 5806-5812.

43 R. D. Shannon, Acta Cryst., 1976, A32, 751-767.

44 Seventeen CSD entries contain a 2-phenyl-1,2benzoselenazol-3 $(2 \mathrm{H}$ )one moiety having a hydrogen atom on C7 (Table S.10). Sixteen of these structures show the presence of a bifurcated $\mathrm{C} 7-\mathrm{H} \cdots \mathrm{O} / \mathrm{N} \cdots \mathrm{Se}-\mathrm{N}$ supramolecular synthon and one structure shows neither the $\mathrm{C} 7-\mathrm{H} \cdots \mathrm{O} / \mathrm{N} \mathrm{HB}$ nor the $\mathrm{N}-\mathrm{Se} \cdots \mathrm{O} / \mathrm{N}$ ChB. While these numbers are too small to allow for statistical conclusions to be drawn, they indicate that the bifurcated $\mathrm{C} 7-\mathrm{H} \cdots \mathrm{O} / \mathrm{N} \cdots \mathrm{Se}-\mathrm{N}$ supramolecular synthon is preferred over the monofurcated $\mathrm{C} 7-\mathrm{H} \cdots \mathrm{O} / \mathrm{N} \mathrm{HB}$ and the $\mathrm{N}-\mathrm{Se} \cdots \mathrm{O} / \mathrm{N} \mathrm{ChB}$.

45 P. C. Ho, P. Szydlowski, J. Sinclair, P. J.W. Elder, Joachim Kübel, C. Gendy, L. Myongwon Lee, H. Jenkins, J. F. Britten, D. R. Morim.and I. Vargas-Baca, Nature Comm. 2016, 7, 11299.

46 B. R. Beno, K.-S. Yeung, M. D. Bartberger, L. D. Pennington and N. A. Meanwell, J. Med. Chem., 2015, 58, 4383-4438.

47 (a) S. Benz, A. I. Poblador-Bahamonde, N. Low-Ders and S. Matile, Angew. Chem. Int. Ed., 2018, 57, 5408-5412; (b) P. Wonner, L. Vogel, M. Dgser, L. Gomes, F. Kniep, B. Mallick, D. B. Werz and S. M. Huber, Angew. Chem. Int. Ed., 2017, 56, 12009-12012.

48 (a) L. M. Lee, M. Tsemperouli, A. I. Poblador-Bahamonde, S. Benz, N. Sakai, K. Sugihara and S. Matile, J. Am. Chem. Soc., 2019, 141, 810-814; (b) A. Borissov, I. Marques, J. Y. C. Lim, Vítor Felix, M. D. Smith and P. D. Beer, J. Am. Chem. Soc. 2019, 141, 4119-4129. 